\title{
Comparing how peace operations enable or restrict the influence of national staff: Contestation from within?
}

Cooperation and Conflict 2019, Vol. 54(4) 488-505

(C) The Author(s) 2018

Article reuse guidelines: sagepub.com/journals-permissions DOI: $10.1177 / 00108367 \mid 8815528$ journals.sagepub.com/home/cac

\section{Steffen Eckhard}

\begin{abstract}
A large share of civilian staff working in international peace operations are nationals of the host state. Academic research has not yet investigated the effect of these locally recruited bureaucrats on peacebuilding. Theoretically, it is argued that to accomplish their missions in complex environments, peace operations require crucial knowledge about local perceptions, politics, and customs. Local staff can have a positive performance impact by soliciting such knowledge. But information advantages create new principal-agent problems. Peace operations have a hard time scrutinizing their employees' allegiances, and they risk sabotage from within. Empirically, it is shown that peace operations conducted by the United Nations (UN), the Organization for Security and Co-operation in Europe (OSCE), and the European Union (EU) differ significantly in how they navigate the ensuing tension by enabling or restricting the influence of their local staff. A new data set on the staffing of 52 peace operations as well as analysis of internal staff policies yields significant variance in the potential of local staff to influence peacebuilding policy implementation, which is most extensive in the OSCE, followed by the UN and the EU. This finding warrants more attention on the role of local staff as information gatekeepers who could be at the center of potential frictions between international and local norms and knowledge.
\end{abstract}

\section{Keywords}

Bureaucracy, international organizations, knowledge generation, local staff, norm contestation, peacebuilding

\section{Introduction}

Peacebuilding is a key tool used by the international community to deliver peace and security in countries plagued by violence. Modern multidimensional peacebuilding includes a host of activities by which outside actors, such as foreign governments, non-governmental

\section{Corresponding author:}

Steffen Eckhard, University of Konstanz, Universitätsstr. 10, 78457 Konstanz, Germany.

Email: steffen.eckhard@uni-konstanz.de 
organizations, and international organizations (IOs), support a recipient state in building liberally oriented, rights-based state institutions embedded in the rule of law. The focus of this article is on multilateral peace operations by the United Nations (UN), the European Union (EU), and the Organization for Security and Co-operation in Europe (OSCE). The term 'peace operation' captures the administrative setting in which peacebuilding policy implementation takes place, which usually unfolds in the form of a field mission.

As outside actors, peace operations navigate a boundary between international and local. In this article, the term 'local' refers to anything that is not international. This is opposed to the use of 'local' as a designation of state levels (capital versus community). It is rarely recognized that the majority of the civilian staff working in peace operations are locally recruited. These are individuals who do not pursue an international IO career and are predominantly nationals of the host state (henceforth local or national staff). In 2015 , as many as $80 \%$ of the civilian staff in some UN missions were recruited locally. In OSCE missions, the average local-staff share was $75 \%$, stretching to $93 \%$ in one case (see Figure 1(b) below). Despite the imbalance between the number of local and international personnel, the planning and implementation of peace operations is generally assumed to be driven by 'internationals.' While some studies question this assumption (e.g., Autesserre, 2014, 2017), surprisingly, researchers have not asked about the specific impact that national staff have on the conduct and outcome of peacebuilding missions (but see Eckhard, 2014).

This article is a first step toward filling this void in international studies, both theoretically and empirically. Key to the argument is the observation of a discernible local turn in the practice of multidimensional peace operations, including such key principles as local ownership and bottom-up peacebuilding (for an overview, see Leonardsson and Rudd, 2015). The local turn dovetails with the acknowledgment of the paramount importance of local information - knowledge of the history, politics, customs, and societal environment of the host state and its inhabitants - to peacebuilding operations (e.g., Bliesemann de Guevara and Kostić, 2017; Bueger, 2015; Da Costa and Karlsrud, 2012, 2013; Verkoren, 2006). The assumption is that if peacebuilders were better able to integrate the " "banality" of the everyday challenges' (Mac Ginty, 2014: 548), this would lead to better peacebuilding (Hirblinger and Simons, 2015). Others, however, warn that frictions may emerge when international and local norms meet (Björkdahl and Gusic, 2015; Björkdahl and Höglund, 2013; Hellmüller, 2013; Millar et al., 2013; Schia and Karlsrud, 2013; Tholens and Groß, 2015).

Although local staff in peace operations are a cornerstone of local-international interaction, their role and policy impact is not well understood. This article argues that local staff are likely to perform a crucial bridging function between frequently rotating international peacebuilders and the local societal context. By supplying international peacebuilders with knowledge on the local context-both formally as part of their job description and informally per casual exchange-local staff can have a positive impact on the performance of peace operations (local linkage). But, such information advantages create new principal-agent problems. Peace operations have a hard time scrutinizing their employees' real allegiances, and they risk being sabotaged from within (local capture). How peace operations navigate this tension by enabling or restricting the local footprint in their operations is the empirical focus of this article. ${ }^{1}$ 
The article compares the potential influence of local staff in peace operations by the $\mathrm{UN}$, the OSCE, and the EU, understood as the scope of opportunities that exist for local staff to feed local information into the policy implementation process. Data are derived from qualitative research interviews and a novel data set of the number of local staff in 52 field missions belonging to the UN, the OSCE, and the EU between 2000 and 2016 (see data set in Supplementary material), as well as the three IOs' staff policies and relevant guidance documents. The article finds that there are significant opportunities for local staff in the OSCE, and more moderate opportunities in the UN, to feed local information into policy implementation processes. By contrast, the scope for such information linkage is significantly narrower in EU missions. Policy documents also show that peace operations, at least in the UN, purposefully restrict the leeway of local staff, which highlights the possible ambivalence of local staff policy influence.

This article makes contributions to the study of peacebuilding interventions. A growing literature addresses the role of local agents in the context of local ownership (e.g., Donais, 2012; Von Billerbeck, 2015, 2017; Wilén and Chapaux, 2011), local knowledge generation (e.g., Bliesemann de Guevara and Kostić, 2017; Bueger, 2015; Da Costa and Karlsrud, 2012, 2013; Verkoren, 2006), and contestations between international and local norms (e.g., Björkdahl and Gusic, 2015; Björkdahl and Höglund, 2013; Hellmüller, 2013; Millar et al., 2013; Tholens and Groß, 2015). This article theorizes that peace operations may be challenged not only from the outside but also from within by local staff. The empirical finding of variance in opportunities for local-staff policy influence is indicative of this argument and merits further research. This finding also corresponds with recent calls for a more nuanced understanding of the diversity of local actors in post-war peacebuilding (Hughes et al., 2015; Paffenholz, 2015).

\section{The local knowledge gap in peace operations}

Since the first UN operations in the 1960s, peacekeeping has evolved significantly to encompass a host of activities now known broadly as peacebuilding (see, for instance, the 1992 Agenda for Peace or the 2008 Capstone Doctrine). Modern multidimensional peacebuilding operations seek to deliver a broad array of services, including security, and attempt to build peace from the bottom up. This reflects a notable 'local turn,' following the argument that integrating the perspectives and customs of the local society (including at sub-national levels) into the peace processes and any political settlement is key to more effective peacebuilding (for an overview, see Leonardsson and Rudd, 2015).

At the heart of this local turn is the nature of international peace operations as external actors who lack knowledge about the local context. Professional peacebuilders are international experts who usually make a career by rotating frequently between countries and missions. Within the expert community, methodological training and expertise in various peacebuilding techniques and comparative experience from more than one context is valued over specific country knowledge (Englebert and Tull, 2008: 134). Language deficits also prevail. For instance, out of the $1700 \mathrm{UN}$ police officers deployed in Haiti in 2005, only 100 spoke French or Creole (Meharg, 2009: 136). This language deficit, combined with limited resources and time constraints, incentivizes peacebuilders to make assumptions and to take shortcuts in interpreting and responding to their environment (Autesserre, 
2014: 68-96, cf. Autesserre, 2017, 12). Instead of a solid cultural understanding of the country they came to assist, peacebuilders often rely on abstract ideas about what works and what doesn't work that are reinforced through workshops and are transplanted in any conflict and post-conflict context (Verma, 2011: 59). By contrast, the local turn in peacebuilding research implies that 'getting our understanding of the local right, and devising governmental strategies according to its true nature, could lead to better peacebuilding' (Hirblinger and Simons, 2015: 423).

Academic literature on the local turn and its implications is based mostly on a social constructivist reasoning that emphasizes the relevance of ideas, values, and norms for actor identities and interests, and thus peacebuilding actions and outcomes (see, Björkdahl, 2002). Within this broad strand of literature, three key claims are important to better understand the deficits of peace operations as outside actors.

The first argument is the normative call to enhance local ownership of the peace process, understood as 'the degree of control that domestic actors wield over domestic political processes' (Donais, 2012: 1). In a post-conflict context, efforts to establish local ownership rest on the recognition that peace efforts will fail if citizens do not perceive them as legitimate. Local ownership is usually operationalized by formally integrating local society representatives into the formal peacebuilding process (Von Billerbeck, 2015, 2017; Wilén and Chapaux, 2011).

The second argument emphasizes the importance of understanding how local norms and knowledge are generated. In order to be effective, peace operations depend on understanding the local environment they operate in, including its customs, culture, and politics (Bliesemann de Guevara and Kostić, 2017; Da Costa and Karlsrud, 2012, 2013). Mac Ginty (2014: 561), for instance, argues that peace initiatives rooted in 'everyday peace,' understood as routinized social practices used by individuals in conflict societies, 'may have a chance of legitimacy and authenticity that may be lacking from imported initiatives.' It is therefore crucial to understand how local knowledge emerges and by which mechanisms it is generated. For instance, it has been observed that, in conflict situations, certain problems and solutions often emerge as known and given (Danielsson, 2017). Others point to the role of distinctive gatekeeper entities that 'make things known' (Bueger, 2015) and the interaction between various professional epistemic communities and their knowledge networks (Verkoren, 2006).

The third argument touches upon the dynamics of contestation between local and international knowledge and norms. Peacebuilding takes place at critical moments, when ideas about future forms of government and policies are in flux. In this context, authors emphasize the 'normative power' of local actors who negotiate and contest the meaning of international norms and adjust them to local conflict realities (Groß, 2015; Tholens and Groß, 2015). Authors also problematize that 'frictions' can emerge during this process (Millar et al., 2013; Schia and Karlsrud, 2013). Hellmüller (2013) argues that local and international peacebuilding actors have different perceptions about the causes of conflict, and, thus, the peacebuilding solution they respectively deem effective. While this is one possible source of friction, Björkdahl and Höglund (2013: 290) more generally warn against 'romanticizing the local.' Based on the notion of local resistance, Björkdahl and Gusic (2015) propose several behavioral patterns on the side of 'local agents' who could either assist in localizing international peacebuilding norms or, conversely, work toward undermining them. 
Little attention has been devoted to studying the role of nationally recruited staff in peace operations. Although termed 'international,' peace missions usually do not consist solely of internationally recruited experts; many personnel are also recruited in the host state. The UN, for example, has two local-staff categories - national professional officers (NPOs) and general service (GS) personnel ${ }^{2}$ — who work opposite the international professional staff (IPS), who hold key management positions in peace missions. Individuals who are born in the country where a peace mission deploys possess the very contextual knowledge that international experts lack, including language and understanding of local customs and politics. Being both members of the local society and part of the external peace missions, these local staff could, for instance, internalize some of the frictions between international and local norms. The next section explores in greater detail the potential impact of local staff on the implementation of peacebuilding policy.

\section{How local staff affect policy implementation in peace operations: contestation from within?}

Little is known about how IOs in general, and peace missions in particular, employ local staff and how this in turn affects their operations. A systematic literature review yielded not a single study addressing the role of local staff in peace operations as a stand-alone phenomenon. ${ }^{3}$ But this does not mean that theorizing the impact of local bureaucrats on peacebuilding policy implementation takes place in a void. The above literature on the local turn offer important starting points, as well as research in the field of public administration.

A theory known as 'bureaucratic representation' explicitly acknowledges the cultural, social, and economic ties between bureaucrats and societal communities (Kingsley, 1944). Traditionally, bureaucratic representation theory is concerned with heterogeneous Western societies, and argues that a bureaucracy that mirrors the ethnic composition of a society produces 'policies that are democratic in the sense that they are generally responsive to the desires of the public' (Kingsley, 1944; Meier, 1993: 2). While researchers traditionally assume individual-interest representation and positive discrimination as key mechanisms, representing bureaucrats could also provide knowledge of their social groups, which is critical for the performance of their employing agency. Depending on their social origin, bureaucrats can bridge the knowledge gap about a broad range of societal-group interests, including the management of relations and the provision of factual information (Eckhard, 2018). Such linkage has been observed for the national origin of bureaucrats in the EU (Gravier, 2013) and the ethnic origin of South African streetlevel bureaucrats (Fernandez et al., 2017), and it should also apply to locally recruited bureaucrats in other IOs.

But the possession of advanced information about the implementation context provides locally socialized bureaucrats with an information advantage. This creates new principal-agent problems in IO field offices, such as peace operations, where international staff work alongside local colleagues. Local bureaucrats could secretly try to influence service provision by peace operations, such as the areas patrolled by blue helmets or barrettes or the locations of aid-delivery projects. Such actions would then undermine impartiality, which is a principle to which outside peacebuilders usually aspire. For instance, one case study on the UN interim administration mission in Kosovo found that 
the mission failed to implement affirmative policies benefiting the (now) Serb minority because its interim administration predominantly employed local ethnic Albanian civil servants who opposed delivering benefits to their former 'oppressors' (Eckhard, 2014). Single case studies on foreign aid indicate that local capture is also a relevant problem there (Gibson, 2005; Platteau, 2004) and case studies on humanitarian assistance demonstrate how local elites can capture the delivery of international aid to serve their own political interests (Owen, 2010; Takasaki, 2011).

While not referring to local staff directly, peacebuilding literature also reflects the possible tension between linkage and local capture. In particular, Björkdahl and Gusic's (2015) work on frictions between local and international norms distinguishes three behavioral patterns on the side of local agents: localizing (adjusting international norms to the local context), co-opting (hijacking norm adjustment processes to serve their own interests), and counteracting (rejecting and undermining international norms). Such patterns could also be prevalent among local staff in peace operations. Indeed, studies indicate that the idea of local resistance is prevalent among international UN staffers who were found to 'share a conviction that local actors will not act according to the broadly liberal principles of the UN, including democracy' (Von Billerbeck, 2015: 302). Súilleabháin (2015: 54) equally suggests that 'international actors should be aware that gatekeepers among organized civil society and national elites may prevent them from reaching perspectives and policy preferences that are representative of the broader population.'

Overall, while there is little doubt that local staff affect peace operations in some way, the literature is disunited regarding the exact impact of local staff (as one group of local agents) on peace operations. On the one hand, a beneficial performance effect is possible when local staff act as interlocutor and improve information flows. On the other hand, counteracting or local capture is also possible when local staff exploit information advantages. As of yet, there is a lack of both a systematic empirical assessment of these two outcomes and a theory to explain the conditions under which one or the other occurs.

\section{Operationalizing the potential influence of local staff on policy implementation}

As a first step toward developing a theory of how local staff affect policy implementation in peacebuilding (and possibly beyond), this article focuses on the institutional opportunities that local staff have to influence policy implementation, captured by the phrase 'potential influence on policy implementation.' Drawing on bureaucratic influence literature, the term 'influence' is used synonymously with 'having an effect' (Biermann and Siebenhüner, 2009: 40; Eckhard and Ege, 2016: 964). Thus, 'influence' refers to a causal reasoning of one actor changing the behavior of other(s) (Cox and Jacobson, 1973: 3). Importantly, influence 'potential' is not so much about causal claims that A has an effect on B, but rather about the opportunity to exercise influence (i.e., to have an effect). According to this perspective, one must differentiate 'between the exercise of power when A induces, forces or compels B to do something that B would not otherwise do and the bases of power or the resources that allow for its exercise' (Lowery, 2013: 3). With information advantages as their main power resource, the focus here is hence on 
institutional opportunities of local staff to feed information about the local context to peacebuilding policy implementation processes.

All processes in organizations are essentially social, which is why previous scholars differentiate formal and informal opportunities for influence (March and Olsen, 1989). Thereby, characteristics of an organization that are laid down in writing (e.g., in statutes, administrative acts, organization charts, memoranda, contracts, etc.) are called 'formal' (Scott and Davis, 2007: 22f). By contrast, characteristics that are not captured in official documents but relate to an organization's actual functioning are termed 'informal' (Bohne, 2010: 27). The potential influence of local staff thus depends on their formal involvement in policy implementation decision making and the scope of informal interaction with managing staff members (i.e., international staff). Three indicators can be used to assess the potential extent of this influence:

The first indicator $\left(\mathrm{I}_{1}\right)$ is the relative numerical share of local versus international staff in peace operations. This assumes that the higher the percentage of local staff compared with international staff, the more pronounced their potential influence. On the one hand, this is simply because a larger share of local staff means that more tasks are performed by these individuals. On the other hand, this indicator speaks to the informal dimension of influence and acknowledges that information can also be passed on informally, say through chatting over lunch or during casual encounters (Farrell and Héritier, 2003; West, 2004). Thereby, a higher share of local staff implies more opportunities for informal exchange.

The second indicator $\left(\mathrm{I}_{2}\right)$ is the formal job profile of local staff. Do they execute support functions only, or are they assigned substantive tasks related to the implementation of the peacebuilding mandate? If the latter is the case, it is also relevant whether job descriptions require local staff to execute tasks that explicitly aim to connect the international with the local context. The underlying assumption is that the more explicitly local staff perform functions linked to the local context, the higher their potential influence on implementation.

Finally, a third indicator $\left(\mathrm{I}_{3}\right)$ captures formal measures that peace operations enact to restrict the discretion or influence of local staff. This includes whether local staff can assume supervisory management functions with decision-making authority and staff responsibility. Another question is whether policies exist that limit the information advantage of local staff, for instance by formalizing how local-context information is gathered. The underlying assumption is that the higher the extent of discretion local staff have in the execution of their tasks, the more pronounced their potential influence on implementation.

\section{The potential influence of local staff on peacebuilding policy implementation by the UN, the OSCE, and the EU}

Empirically, the above indicators are assessed quantitatively $\left(\mathrm{I}_{1}\right)$ and qualitatively $\left(\mathrm{I}_{2}, \mathrm{I}_{3}\right)$ for three IOs in the field of peacebuilding. The UN is the largest actor and has implemented peace operations since the 1960s. The other two organizations are regional and entered the field of peacebuilding policy implementation after the end of the Cold Warthe OSCE with its network of field offices and missions, and the EU with its Common 
Table I. Overview of the data set on local staff in peace operations.

\begin{tabular}{|c|c|c|c|c|c|c|c|c|c|}
\hline \multirow[t]{2}{*}{10} & \multirow{2}{*}{$\begin{array}{l}\text { Period } \\
\text { covered }\end{array}$} & \multirow[t]{2}{*}{ \# missions } & \multirow{2}{*}{$\begin{array}{l}\text { Average } \\
\text { staff per } \\
\text { mission }\end{array}$} & \multirow{2}{*}{$\begin{array}{l}\text { Average \% } \\
\text { of civilian } \\
\text { staff per } \\
\text { mission }\end{array}$} & \multicolumn{5}{|c|}{$\%$ of local civilian staff per mission } \\
\hline & & & & & Min. & Max. & Mean & Std. & Conf. (.95) \\
\hline UN & $2000-2016$ & 25 & 9025 & 17.68 & 23.62 & 80.87 & 58.14 & 11.68 & 1.52 \\
\hline OSCE & $2004-2015$ & 13 & 228 & 100.00 & 35.09 & 93.48 & 75.57 & 9.66 & 1.58 \\
\hline EU & $2006-2015$ & 14 & 371 & 100.00 & 0.00 & 70.00 & 33.83 & 16.88 & 3.76 \\
\hline
\end{tabular}

Source: Author's illustration (for data, see Supplementary material). UN missions also include military and police units used to patrol streets and stabilize countries; these personnel are not counted as civilians with substantive peacekeeping tasks. Because of their primary task profile as project managers and capacity builders, police staff in EU missions were counted as civilians.

Security and Defense Policy. Lack of data precluded the inclusion of NATO or African Union missions. The three selected organizations are representative of peacebuilding executed by IOs (as opposed to non-governmental actors or nation-states executing peacebuilding tasks as part of their foreign, defense, or aid policies).

Data on $\mathrm{I}_{1}$ are extracted from the annual budget sheets of the UN and the OSCE and were provided by the Stockholm International Peace Research Institute (SIPRI) for the EU (see Supplementary material for more details on data sources). The resulting data set is longitudinal and covers the staffing of 52 peace missions by the three IOs over a period of at least 10 years for each IO (see Table 1). To assess the representation of local staff in each mission, the number of civilian personnel was taken from the budget sheets and the rate calculated of local versus international employees. In the UN and the OSCE, 'local staff' includes the staff groups National Professional Officers and General Service, whereas 'international staff' includes the staff group International Professional Staff (ST/ $\mathrm{SGB} / 2014 / 1$ ). For the EU, there is only one local staff group (the local agent) and one international staff group. Using the total number of civilian personnel per mission rather than total personnel as a reference avoids distortions, given that several UN missions come with large military and/or police components that are used to establish a secure environment in the country of operation. This is not the case in the EU and the OSCE missions in the data set.

Data on $\mathrm{I}_{2}$ and $\mathrm{I}_{3}$ are drawn from administrative documents, such as staff policies and internal guidelines. These documents were identified and retrieved through desk-based internet research and nine background interviews with officials from the three organizations during 2017/2018 (EU Official 1, EU Official 2, EU Official 3, EU Official 4, OSCE Official 1, OSCE Official 2, OSCE Officials 3, UN Official 1, UN Official 2). All organizations provided access to additional internal documents; in the EU case, these documents were provided for visual inspection during the interviews only. There is also substantial public information available on UN staff policies and practice.

\section{$\mathrm{I}_{1}:$ the relative share of local versus international staff}

To first assess the numerical representation of local staff in peace operations, the staffing patterns of 52 field missions by the UN, the OSCE, and the EU peace missions are 


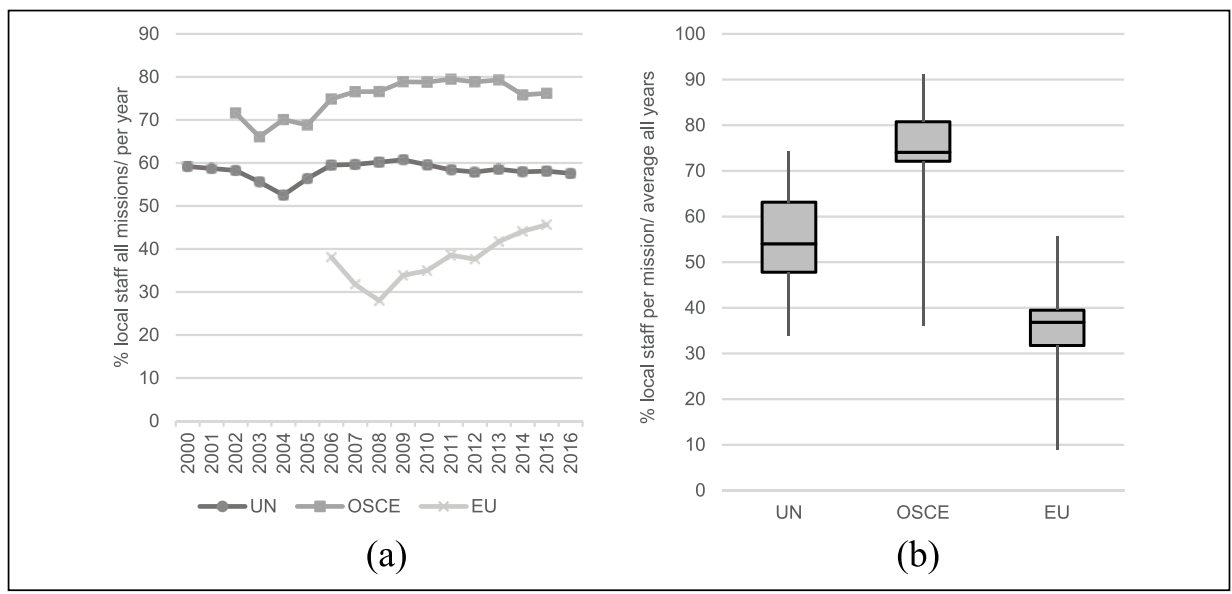

Figure I. National share of all civilian staff in peace operations over time (a) and between organizations (b).

Source: Author's illustration (for data, see Supplementary material). Note that Figure I(a) is based on one observation per mission (all years), whereas Table I is based on one observation per mission and year.

compared. ${ }^{4}$ First, as Figure 1(a) shows, the percentage of local staff is highest in OSCE missions, with an average of $75 \%$ in all observed missions and years, and lowest in EU missions, with $33.8 \%$ on average. The UN sits between, with $58.1 \%$. Over time, both the $\mathrm{UN}$ and the OSCE are relatively constant in their share of local employees, while the EU varies significantly because of the higher volatility of EU missions. In all missions, the share of local staff is lower in the 1styear of deployment because local staff first has to be recruited. The share then quickly increases to a more stable value for the remaining years. The marginal impact of this volatility effect decreases with the time span of mission deployment. In line with this, the average duration of UN and OSCE missions is 157 and 215 months, respectively, whereas the average duration of EU missions is only 82 months.

Second, the data also allows assessing variation in local-staff shares between individual missions. Figure 1(b) compares the average share of local staff per mission covering all years that each mission was deployed. The dispersion of local-staff shares per organization shows that there is notable variance between missions. In the UN, the average share of local staff is highest in the UN mission in Cypris (UNFICYP: $74.36 \%$ ) and in the Iraq-Kuwait Observation Mission (UNIKOM: $71.55 \%$ ) and lowest in the UN mission in the Central African Republic (MINUSCA: 39.74\%) and the United Nations Interim Security Force in Abyei mission at the border between Sudan and South Sudan (UNISFA: $33.94 \%$ ). Whereas the former two missions are located in relatively peaceful environments, the profile of the latter missions is much more military, which suggests a reason for local-staff share variances between missions. This also corresponds with the patterns in the two other organizations. While the OSCE rarely intervenes in ongoing conflicts, the OSCE missions in Ukraine (OSCE SSM: $36.18 \%$ ) is one notable exception and at the same time has the lowest share of local staff. Likewise, the EU mission with 
the lowest local-staff share was the mission in Iraq (EUJUST LEX: 7.24\%), which also intervened in an ongoing conflict. The EU mission with the highest local-staff share was the EU police mission in Bosnia and Herzegovina, which was relatively stable (EUPM, $53.65 \%) .^{5}$

Overall, the three organizations reveal different patterns in terms of their relative local-staff share, which is highest in the OSCE and lowest in the EU. The observed variance between missions suggests that the peacebuilding environment might affect recruitment of local staff. Missions intervening in an ongoing 'hot' conflict are, for example, more restricted in their scope of peacebuilding activities, which could limit their functional demand for local staff. A more complex environment could also reduce the availability of qualified personnel. These possibilities affect the potential influence of local staff but require more in-depth analysis. For the time being, the interim conclusion is that the potential influence of local staff is generally highest in the OSCE and lowest in the EU, whereas single-mission outliers exist.

\section{$\mathrm{I}_{2}$ : the formal job profile of local staff}

In addition to the relative share of local versus international staff, the formal job profiles of local staff are another indicator that restricts or enables opportunities to influence mandate implementation. In the UN, civilian personnel fall into two categories: professional staff who are substantively involved in peacebuilding activities and support staff who primarily execute administrative activities such as interpreting, security, and logistics. It is worth noting that in the $1960 \mathrm{~s}$, the UN had already created the position of NPO for those local staff who perform substantive tasks. In 1980, the NPO staff category was more formally regulated in acknowledgment of the fact that the very nature of some UN field tasks 'required national knowledge and experience and therefore could not be carried out as effectively by international professionals' (ICSC, 2009, 3f.). Between 2005 and 2009, the number of NPOs increased substantially in the UN system, while the 'largest increases have occurred in the United Nations peacekeeping missions' (ICSC, 2009, 6). According to UN staff policy (ST/SGB/2014/1), ${ }^{6}$ these NPOs 'require as a minimum a first-level university degree' and must be 'nationals of the country in which they are serving.' Furthermore, their 'functions must have a national context, i.e., functions that require national experience or knowledge of the national language, culture, institutions, and systems.' Examples of associated job descriptions include human rights officers, political affairs officers, legal officers, medical officers, child-protection officers, and interpreters. In the UN, around $20 \%$ of local staff (ICSC, 2009, 3f.) thus have formal influence on policy implementation, but exact data for individual missions is unavailable.

The remaining $80 \%$ of local staff are categorized as GS staff. While the potential influence is more pronounced when local staff perform substantive tasks, information linkage can also take place through informal interaction, and thus can be executed by drivers, interpreters, facility service providers, or mechanics who interact with international staff. This argument is supported by a UN study on how peacekeepers gather local information (DFS/DPKO, 2013). ${ }^{7}$ Based on a survey among all UN peacekeeping staff, the study found that, for information on the local context, respondents most frequently $(68 \%)$ ask their national colleagues; the second and third relevant sources of local information are 
local government officials (57\%) and national civil-society organizations (52\%). Summarizing their findings, the study authors write that 'local staff are seen as essential in these [information gathering] efforts, both in soliciting and analyzing local perceptions, both through their own networks and by transmitting information on the perceptions of their own communities to international staff' (DPKO/DFS, 2013, 29). Although the quality of the survey data cannot be assessed, this finding indicates that GS staff have informal influence on policy implementation.

OSCE staff categories are generally modeled along the UN system. Among those categories are national professional positions that require incumbents to hold an academic certificate and local staff positions in the GS category. ${ }^{8}$ Apart from providing job descriptions, the organization's internal staff regulation does not offer specific guidance on the role of local employees (OSCE, 2010), which is left to the discretion of individual missions (OSCE Official 3). But a deployment guide published by the British government highlights that 'local staff in all OSCE field operations are often the key to success. Respecting local staff in their work, for their local knowledge and utilising them fully are the key to a deployee's own success in his/her work' (UK Stabilization Unit, 2014: 27). Overall, the potential influence of local staff job description is thus comparable to the UN.

Finally, the EU is the only organization in the sample in which international staff outnumber locally recruited staff, whom the EU terms 'local agents,' with a ratio of two to one. The EU maintains a network of EU delegation offices around the world for which the staff position 'local agent' was originally designed. But the same rules usually apply to crisis management operations, although missions are free to adjust them on a case-bycase basis (EU Official 3, EU Official 4). The relevant staff policy documents - the 'EU Delegation Guide' and the 'Framework Rules'9 — are not public, but respondents provided information on their content, which was consistent with the third-party documents quoted below. The most important provisions are that local agents 'cannot represent the EU' and that they are 'required to serve as support staff' in functions that are restricted to 'manual or service duties' (CLPHU, 2016, 1). There are, however, five sub-groups, one of which (AD1) includes more independent office tasks, such as political reporting (EU official 1, EU Official 2). While EU local agents in some cases can perform substantive tasks, their formal influence on mandate implementation is much more limited than in the other two organizations.

\section{$\mathrm{I}_{3}$ : formal restrictions and controls}

In the UN, the staff regulations allow local staff contracts to be open-ended (ST/ $\mathrm{SGB} / 2014 / 1$ ), and individuals can be promoted to managerial functions (albeit not to senior leadership functions, which are reserved for international staff). A report by the World Health Organization assessing the use of NPOs in other UN organizations states that NPO staff act 'often in managerial and supervisory roles' (EB95/46). But there is also one formal institutional safeguard. In 2014, the Department for Peacekeeping Operations developed internal guidance on 'Understanding and Integrating Local Perceptions in UN Peacekeeping' (DPKO, 2014). Although significant space is devoted to recommending various models by which information on local staff can be gathered through formal consultation or research, no mechanism is mentioned that explicitly 
draws on consultation with local staff. It is likely that the UN explicitly seeks to limit the influence of local staff as information gatekeepers. This rationale is consistent with the above referenced UN staff survey study (to which the guidance document refers), whose authors warn that 'relying solely on a limited number of established contacts can restrict missions' ability to understand the broad spectrum of local perceptions and can result in bias ... [and] ... inflate the influence of "gatekeepers"" (DPKO/DFS, 2013, 65).

By contrast, the OSCE has not installed policies or guidance to limit the influence of local staff. Although senior management positions are reserved for international staff, it is possible for local professionals to assume team leadership functions that are then reimbursed through special post allowances (OSCE Official 3). As the British delegation guide states, there are many examples of senior local staff who 'have taken on the portfolio of fellow international staff and often work with OSCE international staff on a semi-equal basis in terms of professional responsibility and workload' (UK Stabilization Unit, 2014, 27). One peculiarity of the OSCE is that local staff usually have open-ended contracts, whereas the employment period of international staff per definition is restricted to a maximum period of 10 years (OSCE, 2010, Rule 3.08.1). In line with this, a white paper on the future of OSCE field operations also states that local staff 'contribute significantly to the OSCE's on-site efforts; they constitute an important element of a mission's strength, and are keepers of its institutional memory' (OSCE Network, 2014, 23). Sometimes, the OSCE even uses its local staff as part of its exit strategy to gradually downgrade the international footprint of a mission. One example is the OSCE office in Bishkek, which was established in 1998 with a mandate to support security-sector reform and strengthening democratic institutions, among other responsibilities. In a 2017 revision of the mandate, the OSCE agreed with the Kyrgyz government to devise a 'strategy to gradually hand over managerial positions to competent local staff members' (OSCE, 2017, 33).

Finally, the staff contracts in EU crisis management missions are usually fixed-term, in line with the fixed-term nature of most mission mandates. In reality, contracts usually are extended, and local staff can remain in mission for a long time (EU Official 3, EU Official 4). There are no relevant institutional safeguards within the EU system. Given, however, that local agents in the EU rarely perform substantive tasks, there is limited need for such precautions.

\section{Summary of empirical findings}

Overall, the potential influence of local staff on mission operations differs among the three organizations (see Table 2). In terms of staff policy $\left(\mathrm{I}_{2}\right)$ and formal discretion $\left(\mathrm{I}_{3}\right)$, the potential influence is highest in the OSCE and lowest in the EU, with the UN falling in between. In the OSCE and the UN, local staff perform substantive tasks, can be promoted to management positions, and remain in missions on an open-ended-contract basis. In the UN, there is also administrative guidance that restricts the role of local staff in gathering local knowledge. In the EU, local staff usually do not perform substantive tasks. While these indicators apply to all missions per organization, assessment of the share of local staff $\left(\mathrm{I}_{1}\right)$ revealed both between-organization and between-mission variation. Overall, each indicator individually supports the general conclusion that the OSCE makes most pronounced use of local staff, which is slightly more moderate in the UN. In 
Table 2. Empirical findings on the potential influence of local staff in OSCE, UN, and EU missions.

\begin{tabular}{llll}
\hline & OSCE & UN & EU \\
\hline $\begin{array}{l}\mathrm{I}_{1}: \text { Relative staff share } \\
\begin{array}{l}\text { Percentage of local staff (all missions) } \\
\mathrm{I}_{2}: \text { Formal job profile }\end{array}\end{array}$ & $75 \%$ & $58.1 \%$ & $33.8 \%$ \\
$\begin{array}{l}\text { Support tasks } \\
\text { Substantive tasks }\end{array}$ & Yes & Yes & Yes \\
$\mathrm{I}_{3}:$ Formal restrictions and controls & Yes & Yes & No \\
Employment duration & Open ended & Open ended & Fixed-term \\
$\begin{array}{l}\text { Local staff in supervisory functions } \\
\text { Limitations of information advantage }\end{array}$ & Yes & Yes & No \\
\hline
\end{tabular}

Source: Own illustration.

the EU, local staff are rarely considered a resource for gathering information on the local context, whether formally or informally. These findings must be recognized when devising a formal measure of the actual influence of local staff on policy implementation or organizational performance.

\section{Conclusion: how 'international' are international peace operations?}

The local-turn literature was originally motivated by the assumption that peace operations and their policies are essentially driven by internationals who lack knowledge about the local context. The empirical findings presented here question this assumption at a fundamental level. In the UN and the OSCE in particular, the potential for local-staff influence on peacebuilding policy is significant. Combined with the knowledge gap on the side of many international staffers, it is reasonable to conclude - and scattered evidence in the extant literature supports this conclusion (see, Eckhard, 2014, 2018; Fernandez et al., 2017; Gibson, 2005; Gravier, 2013; Platteau, 2004; Takasaki, 2011) that the potential influence of local staff is also realized in practice.

A growing literature addresses the role of local agents in the context of local ownership (e.g., Donais, 2012; Von Billerbeck, 2015, 2017; Wilén and Chapaux, 2011), local knowledge generation (e.g., Bliesemann de Guevara and Kostić, 2017; Bueger, 2015; Da Costa and Karlsrud, 2012, 2013; Verkoren, 2006), and contestations between international and local norms (e.g., Björkdahl and Gusic, 2015; Björkdahl and Höglund, 2013; Hellmüller, 2013; Millar et al., 2013; Tholens and Groß, 2015). This literature hints to, but has not fully explored, the possibility that the interaction and possible friction between international and local ideas and norms might not be taking place at the boundary between a peace operation and its environment, but right within the organization. We should therefore understand local staff in peace operations as key actors who shape the discursive and interpretive milieu of on-the-ground policy implementation, thus opening up certain lines of action and foreclosing others. As other influential local actors, they appear to be 'entities who make things known' (Bueger, 2015) - gatekeepers who 
generate and distribute (local) knowledge, thus affecting how IOs perceive the situation on the ground and how they subsequently act. Inter alia, this finding is in line with calls for more a nuanced understanding of the diversity of local actors and how they vary in their influence on peace processes (Hughes et al., 2015; Paffenholz, 2015).

It is thus crucial, as a next step, to assess the actual consequentiality of local staff on policy implementation. Policy documents referred to above indicate that IOs expect local staff to affect operations along the two lines suggested above (local linkage versus local capture). But empirical evidence is ambiguous. On the one hand, evidence of performance improvement exists (Fernandez et al., 2017), but not for peacebuilding. On the other hand, one case at least (Kosovo) shows how ethnic bureaucratic drift by local staff can undermine peacebuilding objectives along the lines of local capture or sabotage (Eckhard, 2014); there is also some related evidence in foreign aid delivery (Gibson, 2005; Platteau, 2004; Takasaki, 2011). Speaking to such research, the finding that there is variance in formal and informal opportunities for local staff to influence policy implementation should be recognized as an intervening variable.

Finally, peace operations are not alone in pondering how best to navigate the local interface. Local staff are relevant whenever and wherever IOs implement policy. Although more and more researchers study bureaucracies to learn more about how IOs contribute to world politics (Barnett and Finnemore, 2004; Bauer and Ege, 2012; Dijkstra, 2015; Eckhard and Dijkstra, 2017; Eckhard and Ege, 2016; Goetz and Patz, 2017; Johnson, 2014), the role of local staff has yet to be addressed. It might be possible, for instance, to go one step further and consider the possibility that some of the local framing and fixing of meaning by local staff might feed back to shaping discourses (and policy) in IO headquarters. At the moment, such a possibility must await further study.

\section{Acknowledgements}

The author would like to thank two anonymous reviewers for helpful comments, as well as participants of the peacekeeping workshop at the 4th European Workshops in International Studies (EWIS) at Cardiff University (7-10 June 2017) for comments on an earlier version. I would also like to thank Timo Smit and Jair van der Lijn from the Stockholm International Peace Research Institute (SIPRI) for comments on the original research idea and for sharing data on local staff in EU missions.

\section{Funding}

The author(s) received no financial support for the research, authorship, and/or publication of this article.

\section{Notes}

1. This is not to say that the allegiances of international staff cannot also be problematic. Literature on 'unilateral influence' has shown that international staffers can also deviate from their agency objectives along the interests of the state that buttresses them. For an example in the field of peace operations, see Eckhard and Dijkstra's (2017) study on Kosovo.

2. See UN careers website: https://careers.un.org/lbw/home.aspx?viewtype=SC. Note that while GS staff are mostly recruited locally, this staff category can, '[u]nder special circumstances,' also include internationally recruited staff (ST/SGB/2014/1, para 4.4 (a) and 4.5 (c)). 
3. A systematic literature review based on Thomas Reuter's Web of Science Core Collection (211 results) yielded not a single study whose main emphasis was on local staff. The search term was the common occurrence of the keywords 'peacebuilding' and 'local staff' in terminological variations and using truncations and wildcards. Specifically, the search included the following terms: TOPIC: (peace*keeping OR peace*building OR state*building OR nation*building OR 'field mission*' OR 'peace operation*') AND TOPIC: (representation OR representative* OR legitimacy OR ownership OR capture OR lobbying OR 'local staff' OR 'local personnel' or 'national staff') and was refined by: LANGUAGES: ( ENGLISH ) AND DOCUMENT TYPES: (ARTICLE ) Timespan: All years. Indexes: SCI-EXPANDED, SSCI, A\&HCI, CPCI-S, CPCI-SSH, ESCI. https://apps.webofknowledge.com/ (accessed February 2017).

4. Only missions with more than 50 employees during at least 1 year of the observed period are covered. For the UN, only missions run by the Department for Peacekeeping Operations are covered. This excludes from the data set political missions operated by the Department for Political Affairs. The reason for this exclusion is that the latter are funded through a different mechanism that prevented data access. For the EU, only the civilian crisis-management missions were included because military missions rarely employ any local staff at all. For the OSCE, both long-term missions and country offices are covered.

5. The average local-staff share was even higher in the EU Aceh Monitoring Mission in Indonesia (AMM, 55.5\%), though the mission was deployed for only 1 year (2006).

6. Quotes are taken from the UN careers website: https://careers.un.org/lbw/home. aspx? viewtype=SC (last accessed September 2018).

7. More precisely, the question states, 'Who are your interlocutors when gathering information on local perceptions?' Twenty-two possible categories were offered. For each, respondents could choose between five answers: Not at all, Sometimes, Frequently, All the Time, Not Applicable. The question was answered by 380 individuals (DPKO/DFS, 2013, 25).

8. See OSCE employment website: https://employment.osce.org (last accessed September 2018).

9. The Framework Rules lay down the conditions of employment of local staff serving in nonmember countries, as adopted by the Commission on 21 November 1989.

\section{Supplementary Material}

For supplementary material, please see author's personal website.

\section{ORCID iD}

Steffen Eckhard (iD https://orcid.org/0000-0002-5320-0730

\section{References}

Autesserre S (2014) Peaceland: Conflict Resolution and the Everyday Politics of International Intervention. Cambridge: Cambridge University Press.

Autesserre S (2017) International peacebuilding and local success: Assumptions and effectiveness. International Studies Review 19: 114-132.

Barnett M and Finnemore M (2004) Rules for the World: International Organizations in Global Politics. Ithaca, NY: Cornell University Press.

Bauer MW and Ege J (2012) Politicization within the European Commission's bureaucracy. International Review of Administrative Sciences 78: 403-424.

Biermann F and Siebenhüner B (2009) Managers of Global Change. The Influence of International Environmental Bureaucracies. Cambridge, MA: MIT Press. 
Björkdahl A (2002) Norms in international relations: Some conceptual and methodological reflections. Cambridge Review of International Affairs 15: 9-23.

Björkdahl A and Gusic I (2015) 'Global' norms and 'local' agency: Frictional peacebuilding in Kosovo. Journal of International Relations and Development 18: 265-287.

Björkdahl A and Höglund K (2013) Precarious peacebuilding: Friction in global-local encounters. Peacebuilding 1: 289-299.

Bliesemann de Guevara B and Kostić R (2017) Knowledge production in/about conflict and intervention: Finding 'facts', telling 'truth'. Journal of Intervention and Statebuilding 11: 1-20.

Bohne E (2010) The World Trade Organization: Institutional Development and Reform. Basingstoke: Palgrave Macmillan.

Bueger C (2015) Making things known: Epistemic practices, the United Nations, and the translation of piracy. International Political Sociology 9: 1-18.

Cox RW and Jacobson HK (1973) The Anatomy of Influence: Decision Making in International Organization. New Haven, CT: Yale University Press.

Da Costa DF and Karlsrud J (2012) Contextualising liberal peacebuilding for local circumstances: Unmiss and local peacebuilding in South Sudan. Journal of Peacebuilding \& Development 7: 53-66.

Da Costa DF and Karlsrud J (2013) 'Bending the rules': The space between HQ policy and local action in UN civilian peacekeeping. Journal of International Peacekeeping 17: 293-312.

Danielsson A (2017) Programming peacebuilding: Representations, misrepresentations and a shift to the production of interventionary objects. Journal of International Relations and Development. Epub ahead of print 16 November. DOI: 10.1057/s41268-017-0121-1.

Dijkstra H (2015) Shadow bureaucracies and the unilateral control of international secretariats: Insights from UN peacekeeping. The Review of International Organizations 10: 23-41.

Donais T (2012) Peacebuilding and Local Ownership: Post-Conflict Consensus-Building. London: Routledge.

DPKO (2014) Understanding and Integrating Local Perceptions in UN Peacekeeping. UN Guidelines Ref. 2014.08. New York: United Nations Department of Peacekeeping Operations.

DPKO/DFS (2013) Understanding and Integrating Local Perceptions in Multi-Dimensional UN Peacekeeping. New York: United Nations Departments of Peacekeeping Operations and Field Support; Policy, Evaluation and Training Division; Policy and Best Practices Service.

Eckhard S (2014) Bureaucratic representation and ethnic bureaucratic drift: A case study of United Nations minority policy implementation in Kosovo. American Review of Public Administration 44: 600-621.

Eckhard S (2018) Bridging the knowledge gap: Bureaucratic representation as linkage in (international) public administration. In: Representative Bureaucracy Workshop, University of Agder, Kristiansand, 12-14 March 2018.

Eckhard S and Dijkstra H (2017) Contested implementation: The unilateral influence of member states on peacebuilding policy in Kosovo. Global Policy 8: 102-112.

Eckhard S and Ege J (2016) International bureaucracies and their influence on policy-making: A review of empirical evidence. Journal of European Public Policy 23: 960-978.

Englebert P and Tull DM (2008) Postconflict reconstruction in Africa: Flawed ideas about failed states. International Security 32: 106-139.

EU (2016) Note to the attention of Mr. G DI VITA Director General, Budget and Administration, EEAS. CLPHU(16)-SV/HC/ia, 5 October 2016. Brussels: European Commission.

EU Official 1, Human Resource Department in the European External Action Service on 23 January 2017.

EU Official 2, Human Resource Department in the European External Action Service on 23 January 2017. 
EU Official 3, Civilian Planning and Conduct Capability (CPCC) European External Action Service on 24 January 2017.

EU Official 4, Civilian Planning and Conduct Capability (CPCC) in the European External Action Service on 24 January 2017.

Farrell H and Héritier A (2003) Formal and informal institutions under codecision: Continuous constitution-building in Europe. Governance 16: 577-600.

Fernandez S, Koma S and Lee H (2017) Establishing the link between representative bureaucracy and performance: The South African case. 31: 535-553.

Gibson CC (2005) The Samaritan's Dilemma: The Political Economy of Development Aid. Oxford: Oxford University Press.

Goetz KH and Patz R (2017) Resourcing international organizations: Resource diversification, organizational differentiation, and administrative governance. Global Policy 8: 5-14.

Gravier M (2013) Challenging or enhancing the EU's legitimacy? The evolution of representative bureaucracy in the Commission's staff policies. Journal of Public Administration Research and Theory 23: 817-838.

Groß L (2015) The journey from global to local: Norm promotion, contestation and localisation in post-war Kosovo. Journal of International Relations and Development 18: 311-336.

Hellmüller S (2013) The power of perceptions: Localizing international peacebuilding approaches. International Peacekeeping 20: 219-232.

Hirblinger AT and Simons C (2015) The good, the bad, and the powerful: Representations of the 'local' in peacebuilding. Security Dialogue 46: 422-439.

Hughes C, Öjendal J and Schierenbeck I (2015) The struggle versus the song - The local turn in peacebuilding: An introduction. Third World Quarterly 36: 817-824.

ICSC (2009) Review of National Professional Officers: Terms and conditions of service. ICSC/70/R.10. Santiago: International Civil Service Commission (ICSC).

Johnson T (2014) Organizational Progeny: Why Governments Are Losing Control Over the Proliferating Structures of Global Governance. Oxford: Oxford University Press.

Kingsley JD (1944) Representative Bureaucracy: An Interpretation of the British Civil Service. Yellow Springs, $\mathrm{OH}$ : The Antioch Press.

Leonardsson H and Rudd G (2015) The 'local turn' in peacebuilding: A literature review of effective and emancipatory local peacebuilding. Third World Quarterly 36: 825-839.

Lowery D (2013) Lobbying influence: Meaning, measurement and missing. Interest Groups \& Advocacy 2: 1-26.

Mac Ginty R (2014) Everyday peace: Bottom-up and local agency in conflict-affected societies. Security Dialogue 45: 548-564.

March JG and Olsen JP (1989) Rediscovering Institutions - The Organizational Basis of Politics. New York: Free Press.

Meharg SJ (2009) Measuring What Matters in Peace Operations and Crisis Management. Kingston, ON, Canada: Queen's University Press.

Meier KJ (1993) Politics and the Bureaucracy: Policy-Making in the Fourth Branch of Government. Belmont, CA: Wadsworth.

Millar G, van der Lijn J and Verkoren W (2013) Peacebuilding plans and local reconfigurations: Frictions between imported processes and indigenous practices. International Peacekeeping 20: $137-143$.

OSCE (2010) Staff Regulations and Staff Rules. DOC.SEC/3/03, September 2003, Updated: 13 July 2010. Vienna: OSCE.

OSCE (2017) Survey of OSCE Field Operations. Vienna: OSCE. Available at: http://www.osce .org/cpc/74783?download=true

OSCE Network (2014). The Future of OSCE Field Operations (Options). Ankara: OSCE Network. 
OSCE Official 1, Human Resource Department, interview in Vienna on 14 March 2017.

OSCE Official 2, Human Resource Department, interview in Vienna on 14 March 2017.

OSCE Official 3, Human Resource Department telephone interview on 14 December 2017.

Owen JR (2010) 'Listening to the rice grow': The local-expat interface in Lao-based international NGOs. Development in Practice 20: 99-112.

Paffenholz T (2015) Unpacking the local turn in peacebuilding: A critical assessment towards an agenda for future research. Third World Quarterly 36: 857-874.

Platteau JP (2004) Monitoring elite capture in community-driven development. Development and Change 35: 223-246.

Schia NN and Karlsrud J (2013) 'Where the rubber meets the road': Friction sites and local-level peacebuilding in Haiti, Liberia and South Sudan. International Peacekeeping 20: 233-248.

Scott WR and Davis GF (2007) Organizations and Organizing: Rational, Natural, and Open System Perspectives. Upper Saddle River, NJ: Pearson Prentice Hall.

ST/SGB/2014/1 (2014). Staff rules and staff regulations of the United Nations. SecretaryGeneral's Bulletin, 1 January.

Súilleabháin AÓ (2015) Leveraging Local Knowledge for Peacebuilding and Statebuilding in Africa. New York: International Peace Institute.

Takasaki Y (2011) Do local elites capture natural disaster reconstruction funds? The Journal of Development Studies 47: 1281-1298.

Tholens S and Groß L (2015) Diffusion, contestation and localisation in post-war states: 20 years of Western Balkans reconstruction. Journal of International Relations and Development 18: 249-264.

UK Stabilization Unit (2014) Working in a Mission for the Organisation for Security and Cooperation in Europe. London: UK Stabilization Unit. Available at: http://sclr.stabilisatio nunit.gov.uk/publications/deployee-guide-series/498-deployee-guide-osce/file

UN Official 1, ombudsman institution in Nairobi, telephone interviews on 16 June 2017 and 15 November 2017.

UN Official 2, UN mission in Darfur (UNAMID), telephone interview on 28 December 2017.

Verkoren W (2006) Knowledge networking: Implications for peacebuilding activities. International Journal of Peace Studies 11: 27-62.

Verma R (2011) Intercultural encounters, colonial continuities and contemporary disconnects in rural aid: An ethnography of development practitioners in Madagascar. In: Hindman $\mathrm{H}$ and Fechter A-M (eds) Inside the Everyday Lives of Development Workers: The Challenges and Futures of Aidland. Boulder, CO: Lynne Rienner Publishers, pp. 59-82.

Von Billerbeck S (2015) Local ownership and UN peacebuilding: Discourse versus operationalization. Global Governance 21: 299-315.

Von Billerbeck S (2017) UN peace operations and conflicting legitimacies. Journal of Intervention and Statebuilding 11: 286-305.

West WF (2004) Formal procedures, informal processes, accountability, and responsiveness in bureaucratic policy making: An institutional policy analysis. Public Administration Review 64: 66-80.

Wilén N and Chapaux V (2011) Problems of local participation and collaboration with the UN in a post-conflict environment: Who are the 'locals'? Global Society 25: 531-548.

\section{Author biography}

Steffen Eckhard is assistant professor for Public Administration and Organization Theory at the University of Konstanz. His research deals with the influence of the administration on policymaking and implementation in national and international public organizations with a focus on crisis management and peace and security governance. 